\title{
Н.В. Ольховик
}

\section{ЗАМЕНА УГОЛОВНОГО НАКАЗАНИЯ В ВИДЕ ШТРАФА: МИФ ИЛИ РЕАЛЬНОСТЬ?}

\begin{abstract}
Рассматриваются проблемы замены уголовного наказания в виде штрафа. Содержатся предложения по совершенствованию действующего уголовного и уголовно-исполнительного законодательства в части уточнения основания замены, права или обязанности суда ее произвести, закрепления организационно-правовых средств, обеспечивающих своевременную уплату осужденным штрафа и его ресоциализацию, реформированию Федеральной службы судебных приставов в свете создания в России службы пробации.
\end{abstract}

Ключевые слова: уголовно-исполнительное право, альтернативы лишению свободы, наказания без изоляциии от общчества, непенитенцииарный режим, итраф, замена итрафа.

Исполнение уголовного наказания в виде штрафа подробно регламентируется Уголовно-исполнительным кодексом РФ (далее - УИК РФ) и Федеральным законом «Об исполнительном производстве. В то же время на практике возникает множество проблем правового и организационного характера, свидетельствующих о необходимости совершенствования законодательства и решения некоторых организационных вопросов деятельности Федеральной службы судебных приставов.

Во-первых, действующее законодательство регламентирует вопросы замены штрафа другим видом наказания только в случае злостного уклонения от уплаты штрафа, назначенного в качестве основного наказания. Замена штрафа, назначенного в качестве дополнительного наказания, другим видом наказания не допускается.

Во-вторых, не менее проблематичным является определение основания замены уголовного наказания в виде штрафа. В ч. 5 ст. 46 УК РФ в качестве такого основания называется злостное уклонение осужденного от его уплаты. Понятие злостного уклонения определяется в ч. 1 ст. 32 УИК РФ, а именно злостно уклоняющимся от уплаты штрафа считается осужденный, не уплативший штраф либо его часть в установленный законом срок. Буквальное толкование этой нормы позволяет суду не учитывать при решении вопроса о замене наказания обстоятельства, связанные с ухудшившимся материальным положением осужденного на момент исполнения штрафа и объективную невозможность уплатить штраф. Однако, как представляется, необходимо более детально рассмотреть вопрос о понятии злостности применительно к уклонению от уплаты штрафа. Данное понятие предполагает объективный и субъективный критерии. Объективный критерий будет выражаться в невнесении суммы штрафа осужденным в установленное время. Субъективный же критерий законодатель в ч. 1 ст. 32 УИК РФ не указал, хотя в юридической литературе он совершенно обоснованно называется [1, С. 148; 2, с. 45]. Аналогичную позицию занимают и практические работники, более половины которых считают, что ч. 1 ст. 32 УИК РФ необходимо дополнить словами «без уважительных причин. Проведенное нами исследо- вание материалов, разрешаемых судом в порядке исполнения приговора о штрафе, позволяет согласиться с Т.Г. Антоновым в том, что суды довольно часто отказывают в удовлетворении представления судебного пристава и не заменяют уголовное наказание в виде штрафа в случае, когда осужденный не уплатил его в установленный срок, но не установлены причины неуплаты [3, с. 4-9]. Поскольку в законе не могут быть предусмотрены все уважительные причины неуплаты штрафа в срок, более конкретно данный вопрос может быть решен в постановлении Пленума Верховного Суда РФ, в котором можно указать, чтобы при рассмотрении материалов о замене штрафа другим наказанием в случае злостного уклонения от его уплаты суд, как и при назначении наказания, учитывает материальное положение осужденного и его семьи, а также принимает во внимание все обстоятельства, результатом которых явилась неуплата штрафа осужденным.

Таким образом, предлагается закрепить в ч. 1 ст. 32 УИК РФ положение, в соответствии с которым злостно уклоняющимся от уплаты штрафа является осужденный, не уплативший штраф либо его часть в установленный законом срок без уважительных причин. На уровне постановления Пленума Верховного Суда РФ следует разъяснить судам обязательность установления неуважительности причин неуплаты штрафа.

В-третьих, проведенное исследование свидетельствует о том, что $83 \%$ представлений судебных приставов о замене штрафа на другой вид наказания, вследствие злостного уклонения от его уплаты, оставляется без удовлетворения по причине невозможности назначения другого вида наказания. В то же время в $17 \%$ случаев суд заменял штраф другим наказанием. Так, по данным Судебного департамента при Верховном Суде РФ в 2014 г. было рассмотрено 17096 представлений о замене штрафа лишением свободы, из них удовлетворено 3032 [4, с. 3]. Исходя из этого, возникает еще один вопрос о том, чем же руководствовался суд, устанавливая вид, срок или размер нового наказания осужденному. Уголовный закон всегда предусматривал возможность замены штрафа в случае злостного уклонения от его уплаты на более строгое наказание. В перво- 
начальной редакции ч. 5 ст. 46 УК РФ 1996 г. закреплялся перечень заменяющих наказаний - обязательные работы, исправительные работы, арест. В действующей редакции предусматривается, что, по общему правилу, штраф заменяется иным наказанием, за исключением лишения свободы. Если же осужденный злостно уклоняется от уплаты штрафа в размере, исчисляемом исходя из величины, кратной стоимости предмета или сумме коммерческого подкупа или взятки, назначенного в качестве основного наказания, штраф заменяется наказанием в пределах санкции, предусмотренной соответствующей статьей Особенной части Уголовного кодекса. При этом назначенное наказание не может быть условным. Однако во всех случаях действующее законодательство не предусматривает правил пересчета штрафа в другие наказания при его замене. Представляется, что такие правила в УК РФ должны быть установлены. На страницах научной печати предлагаются различные варианты определения продолжительности наказаний, заменяемых штраф [5 ].

В-четвертых, буквальное толкование ч. 5 ст. 46 УК РФ свидетельствует об обязанности суда заменить штраф более строгим наказанием в случае злостного уклонения осужденного от его уплаты. Часть 2 ст. 32 УИК РФ также обязывает судебных приставов в случае уклонения осужденного от уплаты штрафа направлять в суд представление о замене штрафа другим видом наказания. Однако в Постановлении Пленума Верховного Суда Российской Федерации от 11 января 2007 г. № 2 «О практике назначения судами Российской Федерации уголовного наказания» отмечается, что штраф, назначенный в качестве основного наказания, в случае злостного уклонения от его уплаты может быть заменен (выделено мной. - H.O.) другим видом наказания. В связи с этим, возникает вопрос о том, обязан ли суд заменять штраф при злостном уклонении осужденного от его уплаты или нет? В научной литературе все чаще говорится о необходимости пересмотра ч. 5 ст. 46 УК РФ и закреплении не обязанности, а возможности суда заменить штраф в случае злостного уклонения осужденного от его уплаты. Как представляется, с такой позицией можно согласиться только в том случае, если суд не установил неуважительности причин неуплаты осужденным штрафа. Но в таком случае не будет и злостного уклонения, в связи с чем суд должен отказать в удовлетворении ходатайства судебного пристава. Таким образом, поскольку злостно уклоняющимся от уплаты штрафа является осужденный, не уплативший штраф либо его часть в установленный законом срок без уважительных причин, то необходимость закрепления в ч. 5 ст. 46 УК РФ не обязанности, а возможности замены уголовного наказания в виде штрафа отсутствует.

В-пятых, поскольку в УК РФ не предусматривается возможность замены штрафа, назначенного в качестве дополнительного наказания, то в случае злостного уклонения от его уплаты взыскание штрафа производится в принудительном порядке. Но осуществить это, как правило, не представляется возможным. Судебный пристав, исполняя уголовное наказание в виде штрафа, получив информацию о наличии или об отсутствии у должника доходов и имущества, не имеет возможности в этом случае применять ограничения по распоряжению имуществом и доходами, имеющимися у должника, в качестве обеспечительной меры на стадии исполнения уголовного штрафа - принудительного взыскания. Оснований для замены штрафа другим видом наказания в случаях, когда у должников отсутствует имущество и доходы, не усматривается, ибо не является доказанным факт уклонения осужденного от уплаты штрафа. При указанных обстоятельствах, с одной стороны, в соответствии с положениями ч. 10 ст. 103 Федеральный закон «Об исполнительном производстве», судебный пристав обязан приступить к принудительному взысканию. С другой стороны, у судебного пристава нет оснований это сделать, поскольку была установлена невозможность принудительного исполнения в связи с отсутствием доходов и имущества у осужденного для уплаты штрафа. Сложившаяся ситуация, как показывает практика, предопределяет фактическое освобождение должника от исполнения назначенного ему уголовного наказания [ 6, с. 3 ].

В-шестых, анализ практики исполнения уголовного наказания в виде штрафа показывает, что деятельность судебного пристава по принудительному взысканию штрафов носит сугубо формальный характер, заключается в периодическом направлении запросов в различные инстанции и посещении осужденного по месту жительства для проверки его имущественного положения. Действующее уголовное, уголовно-исполнительное законодательство, Федеральный закон «Об исполнительном производстве» не предусматривают организационно-правовых средств, стимулирующих самостоятельную уплату осужденным установленного ему штрафа. Прежде всего, в качестве такого средства, действующего по принципу «стимул-поощрение», следует закрепить право осужденного заплатить штраф в меньшем размере, как это уже предусмотрено применительно к административным штрафам.

Кроме этого, в период исполнительного производства среди злостных неплательщиков штрафа по сравнению с общей массой осужденных к штрафу на $14 \%$ больше лиц, которые нигде не работали (80\% против $66 \%$ ). При этом более половины из них не занимались общественно полезной деятельностью более года. Учитывая это, не удивляют и сравнительно небольшие суммы штрафов, от уплаты которых уклонялась эта часть осужденных. В то же время проведенное исследование, свидетельствует и о том, что практически половина осужденных, которым штраф был заменен более строгим наказанием, были в возрасте от 25 до 49 лет, $35 \%$ - от 18 до 24 лет и только $15 \%$ - 50 лет и более. Что касается образовательного уровня, то $30 \%$ осужденных име- 
ли среднее образование, $46 \%$ - среднее специальное, $14 \%$ - высшее профессиональное образование. В этой связи действующее уголовно-исполнительное законодательство должно предусматривать право суда возложить на осужденного к штрафу обязанность работать, а в случае уклонения осужденного от исполнения этой обязанности закрепить возможность суда заменить штраф другим видом наказания по представлению судебного пристава.

Наконец, помощь осужденному и его вовлечение в обычные условия жизни общества под контролем специалистов - один из вариантов сокращения рецидивной преступности. В свете изложенного следует критически отнестись к деятельности судебных приставов, которая не направлена на ресоциализацию осужденных, их воспитание и изменение поведения в целом. Как представляется, судебные приставы должны участвовать в этой работе посредством своевременного информирования других субъектов о необходимости оказания адресной помощи в получении документов, удостоверяющих личность, в трудоустройстве, решении жилищных проблем и т.д.; разъяснения осужденным их прав, реализация которых влияет на исполнение штрафа. Решение же задачи социальной адаптации осужденных без изоляции от общества в целом должно обеспечиваться наличием соответствующих социально-экономических ресурсов, правовой базы, а также целенаправленным взаимодействием разных социальных институтов. На это, в частности, обращают внимание и европейские стандарты в области исполнения наказаний и иных мер уголовно-правового характера, не связанных с лишением свободы. В Правилах о пробации с учетом разнообразия выполняемых этим ведомством функций содержится принцип взаимодействия с другими государственными органами и ор- ганизациями для оказания помощи правонарушителям (п. 12). Это же положение содержится и в п. 15 Европейских правил в отношении несовершеннолетних [7, с. 56]. Более того, проведенное профессором А. Ван Кальмхутом сравнительно-правовое исследование функций европейских служб пробации убедительно доказывает, что эти функции европейские службы пробации осуществляют во взаимодействии с другими субъектами [8, с. 14-15].

В настоящее время в большинстве населенных пунктов России отсутствуют учреждения, выполняющие функцию социальной адаптации осужденных. Не существует и соответствующей нормативной правовой базы. Полагаем, что социальное сопровождение осужденного должно быть индивидуальным. Следует признать, что наиболее эффективно эти вопросы решаются в тех регионах, где налажено взаимодействие с органами местного самоуправления и общественными институтами. Необходимо создать общественно-государственную систему социальной адаптации осужденных, включающую не только органы и учреждения, исполняющие уголовные наказания, которые должны только содействовать, готовить осужденных во время отбывания наказания к жизни в обществе, но и региональные службы социального сопровождения указанных лиц, оказывающие содействие лицам, освобождающимся из мест лишения свободы, и осужденным без изоляции от общества, в решении вопросов жилья, трудоустройства, в налаживании и восстановлении социально-полезных связей, бесплатной психологической и юридической помощи. Эти службы должны находиться в ведении органов социальной защиты населения и основываться на общественно-государственном партнерстве.

\section{ЛИТЕРАТУРА}

1. Уткина C.C. Уголовное наказание в виде штрафа. Томск: Изд-во Том. ун-та, 2004. 166 с.

2. Антонян E.A. Наказания, не связанные с лишением свободы: правовая природа, назначение и исполнение: учеб. пособие. Рязань: Академия права и управления Минюста России, 2005. 96 с.

3. Антонов T.Г. Злостное уклонение от уплаты штрафа, назначенного в качестве уголовного наказания: проблемы толкования норм уголовного и уголовно-исполнительного законодательства // Актуальные проблемы теории и практики исполнительного производства: материалы круглого стола 11 октября 2013 г. Томск: ЦНТИ, 2013. $71 \mathrm{c.}$

4. Сводные статистические сведения о судебной деятельности федеральных судов общей юрисдикции и мировых судей за 2014 г. // www.cdep.ru [электронный ресурс]: Официальный сайт Судебного департамента при Верховном Суде РФ. Режим доступа: Компьютер. сеть Науч. б-ки Том. гос. ун-та, свободный. Дата обращения: 15.06.2015.

5. Степащин В. Последствия неисполнения уголовного наказания в виде штрафа. http://justicemaker.ru/view-article. php?id=21\&art=1535 [электронный ресурс]: Режим доступа: Компьютер. сеть Науч. б-ки Том. гос. ун-та, свободный. Дата обращения: 15.06.2015.

6. Крименская E.Н. Уголовный штраф за преступление: наказать или простить? // Актуальные проблемы теории и практики исполнительного производства: материалы круглого стола 11 октября 2013 г. Томск: ЦНТИ, 2013. 71 с.

7. Коровин А.А., Хуторская Н.Б. Правовое регулирование и организация деятельности уголовно-исполнительных инспекций на основе реализации европейских стандартов и зарубежного опыта. М.: PRI, 2011. $151 \mathrm{c.}$

8. Van Kalmhout A. Report for the PC-CP meeting, 11 December, 2007. 32 c.

\section{THE SUBSTITUTION OF FINE: MYTH OR REALITY?}

Russian Journal of Criminal Law, 2015, 1(5), 16-19. DOI 10.17223/23088451/5/3

Olkhovik Nikolay V. Tomsk State University (Tomsk, Russian Federation). E-mail: lawtsu@rambler.ru

Keywords: penal law, alternatives to imprisonment, punishment without isolation from society, non-penitentiary regime, fine, substitution of fine. 
The criminal punishment in the form of the fines can cause legal and organizational problems, indicating the need to improve the legislation and to solve some organizational problems of the Federal Bailiff Service. The substitution of fines for other punishments is provided only in the case of malicious evasion of the fine imposed as a principal punishment. The substitution of the fine imposed as a supplementary penalty for another kind of punishment is not allowed. Another problem is how to define the grounds for substitution of criminal punishment in the form of a fine. The norms of criminal and penal legislation compared with the judicial practice do not indicate that the court must substitute the fine for a more severe punishment in the case of the convict's malicious evasion of fine payment. Since the Criminal Code of the Russian Federation does not provide for the substitution of the fine imposed as an supplementary penalty in the case of malicious evasion, and, as stated in Part 3 Article 32 of the Criminal Enforcement Code, in the case of malicious evasion of fine imposed as a supplementary punishment, the fine is enforced, this definition determines the release of debtors from the execution of criminal penalties imposed on them. Finally, the analysed practices of execution of criminal penalties in the form of fines show that the activities of bailiffs connected with the enforcement of fines is reduced to regular inquiring various authorities and visiting the convict's place of residence to check their property. The current criminal and penal law and the Federal Law "On Enforcement Proceedings" fail to provide organizational and legal means to ensure both payment of the fine and re-socialization of the convict.

These problems can be solved by adding the words "without reasonable excuse" to Part 1 Article 32 of the Criminal Enforcement Code of the Russian Federation. The Supreme Court should provide an illustrative list of reasons that can be recognized as reasonable when deciding to substitute the fine for another penalty. Part 5 Article 46 of the Criminal Code of the Russian Federation should enshrine the possibility rather than the obligation to substitute the fine. The principle "stimulus-reward" should imply the right of the convict to pay a smaller fine, as with administrative fines. The current penal legislation should provide for the possibility of imposing the duty work on the person sentenced to the fine, and if the debtor fails to take measures for employment, the court should be entitled to substitute the fine for another penalty upon the recommendation of the bailiff.

\section{REFERENCES}

1. Utkina S.S. (2004) Ugolovnoe nakazanie v vide shtrafa [The criminal penalty of a fine]. Tomsk: Tomsk State University.

2. Antonyan E.A. (2005) Nakazaniya, ne svyazannye s lisheniem svobody: pravovaya priroda, naznachenie i ispolnenie [Penalties not associated with deprivation of liberty: the legal nature, purpose and performance]. Ryazan: Ryazan Academy of Law and Management of the Ministry of Justice of Russia.

3. Antonov T.G. (2013) [Malicious evasion of fine payment imposed as criminal sanctions: problems of interpretation of the criminal and penal legislation]. Aktual'nye problemy teorii i praktiki ispolnitel'nogo proizvodstva [Topical problems of the theory and practice of enforcement proceedings]. Proc. of the Round Table. Tomsk. 11th October 2013. Tomsk: TsNTI.

4. Judicial Department of the supreme Court of the Russian Federation. (2014) Svodnye statisticheskie svedeniya o sudebnoy deyatel'nosti federal'nykh sudov obshchey yurisdiktsii i mirovykh sudey za $2014 \mathrm{~g}$. [Summary statistics on judicial activities of the federal courts and magistrates for 2014]. [Online] Available from: www.cdep.ru. (Accessed: 15th June 2015).

5. Stepashchin, V. Posledstviya neispolneniya ugolovnogo nakazaniya $v$ vide shtrafa [Consequences of the neglected criminal penalty in the form of a fine]. [Online] Available from: http://justicemaker.ru/view-article.php?id=21\&art=1535. (Accessed: 15th June 2015).

6. Krimenskaya E.N. (2013) Ugolovnyy shtraf za prestuplenie: nakazat' ili prostit'? [Fine for the crime: to punish or to forgive?] Aktual'nye problemy teorii i praktiki ispolnitel'nogo proizvodstva [Topical problems of the theory and practice of enforcement proceedings]. Proc. of the Round Table. Tomsk. 11th October 2013. Tomsk: TsNTI.

7. Korovin A.A. \& Khutorskaya N.B. (2011) Pravovoe regulirovanie i organizatsiya deyatel'nosti ugolovno-ispolnitel'nykh inspektsiy na osnove realizatsii evropeyskikh standartov i zarubezhnogo opyta [Legal regulation and organization of penal inspections based on the implementation of European standards and foreign experience]. Moscow: PRI.

8. Van Kalmhout, A. (2007) Report for the PC-CP meeting. 11th December. 